\title{
Standardization of Integrated State Border Post Development
}

\author{
Rachmawati Novaria ${ }^{1}$, Rudy Handoko $^{2}$, Kodrat $^{3}$, Andria Marchelia ${ }^{4}$ \\ ${ }^{1}$ Departement of Public Administration, Faculty of Social Science and Political Science, Universitas 17 Agustus \\ 1945 Surabaya (email: nova@untag-sby.ac.id), ${ }^{2}$ Departement of Public Administration, Faculty of Social Science \\ and Political Science, Universitas 17 Agustus 1945 Surabaya (email: rudyhandoko62@hyahoo.com), \\ ${ }^{3}$ Departement of Public Administration, Faculty of Social Science and Political Science, Universitas Wijaya Putra \\ Surabaya (email: kodrat@gmail.com), ${ }^{4}$ Faculty of Law, Universitas Pembangunan Nasional Veteran Surabaya \\ (email: email: andriamarchelia03@gmail.com)
}

\begin{abstract}
Border areas both on land and at sea as a border of national sovereignty universally have a very important and strategic role, both for national interests and for relations between countries (international). However, the problem that is cross-border in nature is global, especially facing transnational crime that is far more dangerous than military threats. Therefore, solving the problem across borders is not enough to be handled by the Republic of Indonesia itself, but rather by countries in the world to combat transnational crime. A practical and simple step is the need for an agreement between countries at the border to agree to safeguard and maintain cross-border boundaries safely and orderly. Standardization of Integrated PLBN Development includes technical standardization of PLBN buildings and standardization of Integrated PLBN management. In this activity, work will be carried out on the preparation of Integrated PLBN management standardization, which is standardization of the more popular PLBN work mechanism with the term Standard Operating Procedure (SOP) or Fixed Procedure (Protap) to facilitate PLBN officers in understanding PLBN SOPs and at the same time as a base line for basic improvements Future PLBN SOPs.
\end{abstract}

\section{Keywords:}

Standardization, Integrated, State Border

\section{Introduction}

Border areas both on land and at sea as a border of national sovereignty universally have a very important and strategic role, both for national interests and for relations between countries (international). Direct land and sea borders with 3 (three) countries, namely Malaysia, Papua New Guinea and the Democratic Republic of Timor Leste. As an archipelagic state, the Unitary State of the Republic of Indonesia has maritime boundaries in the form of territorial sea boundaries, continental shelf boundaries and Exclusive Economic Zone (EEZ) boundaries, which are jurisdictional boundaries with 9 (nine) countries, namely India, Thailand, Malaysia, Vietnam, the Philippines, Palau, Papua New Guinea, the 
Democratic Republic of Timor Leste and Australia. However, arrangements regarding the management of national borders have so far not been able to run optimally. This can be seen from the unfinished number of problems in the country's territorial boundaries both on land and at sea. Various factors have been identified as a barrier to the low level of resolution of border issues between countries, the most fundamental part is that the border management program has not been integrated in all related sectors. Cross-border problems are global in nature, especially facing transnational crime that is far more dangerous than military threats. Therefore, solving the problem across borders is not enough to be handled by the Republic of Indonesia itself, but rather by countries in the world to combat transnational crime.

Cross Country Border Posts (PLBN) which have inadequate infrastructure facilities must be the focus of attention of the two countries because PLBN is an exit and entry point between countries, including transboundary crime entrances. In addition PLBN is a part that is first seen and encountered by border crossers from neighboring countries so that the good and bad conditions of the PLBN can provide an initial assessment of the condition of a country. In other words, in addition to requiring an orderly and safe PLBn, it is also a StateOwned PLBN that is convenient for border crossers.

PLBN which is a place for Customs, Immigration and Quarantine or CIQ (Custom, Immigration and Quorantine) services as well as a gate that regulates the flow of people and goods in and out of border areas. As a gateway to the country, the availability of PLBN facilities and infrastructure is expected to meet the need to regulate social and economic relations between the people of Indonesia and those in neighboring countries. With the existence of border facilities and infrastructure, this will reduce illegal activities, including the entry and exit of illegal goods. However, the number of PLBNs equipped with factually integrated infrastructure facilities is still minimal. Responding to the phenomenon of border which is very complex, especially the PLBN buildings that have not been integrated and integrated in the CIQ service, it needs to be immediately followed up with the Integrated PLBN Development Standardization Study.

PLBN in Indonesia has the same standard operating procedures. With this SOP, it will facilitate the operation of PLBN with more measurable service results. In addition, the transfer of officers from one PLBN to another PLBN will not face work obstacles because each PLBN has the same procedure. So with SOP there will be standards that can become 
work references, organizations become stronger and team work gets better. In general, it can be said that the SOP will further improve efficiency, effectiveness and accountability in carrying out tasks and help employees become more independent. A management system or process consists of many activities and the management process can only run if every accompanying activity can run well. Each system consists of many sub-systems.

So each process consists of procedures and each procedure consists of activities, which can be simply described as follows:

\section{Figure 1.}

Relationship of Processes, Procedures and Activities

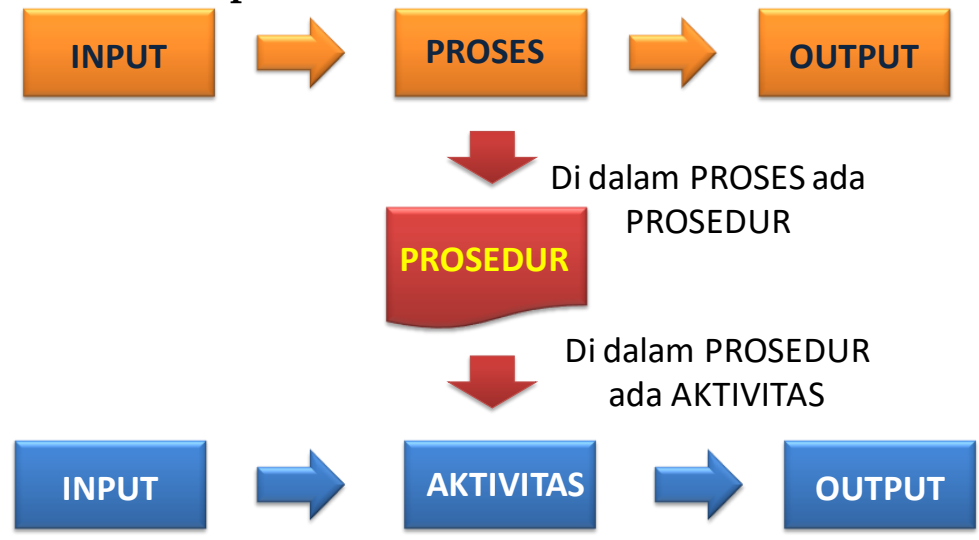

So an SOP needs to be made for each ACTIVITY that accompanies a management PROCESS. Understanding the management process is the entire work process that is in a PLBN (Land) both the scope of the duties of CIQ and UP Integrated PLBN.

\section{Methods}

Data collection activities for the preparation of PLBN Standard Operating Procedures (SOP) are carried out in the following ways: Immigration, Customs and Excise Section, Quarantine Section and UP PLBN; b.) Documents namely data collection carried out using data documents that have been collected by the Immigration Section, the Customs Section, the Quarantine Section and the UP PLBN and the regulations and existing service procedures; c. ) Observation, namely observing various documents and service procedures carried out in the PLBN environment.

Data collection activities for the preparation of PLBN Standard Operating Procedures (SOP) are carried out in the following ways: Immigration, Customs and Excise Section, 
Quarantine Section and UP PLBN; b.) Documents namely data collection carried out using data documents that have been collected by the Immigration Section, the Customs Section, the Quarantine Section and the UP PLBN and the regulations and existing service procedures; c.) Observation, namely observing various documents and service procedures carried out in the PLBN environment.

Data analysis on the preparation of PLBN Standard Operating Procedures (SOP) is carried out qualitatively, namely by explaining in detail the sequence of activities in each activity that is carried out routinely on units in the PLBN

SOP is a work guideline for PLBN employees or officers, so it must be prepared easily and clearly for employees who use the SOP. Thus the nature of the SOP is as follows: a.) The SOP must be oriented towards the user SOP (User guide), not oriented to the Customer's need or the person served by the officer. b.) Easy and clear for SOP users. c.) In line with other SOPs, meaning that there is no conflict with other procedures. d.) Measurable, both in terms of time, cost, quantity and quality. e.) SOP is a legal product, so the enactment of SOP needs to get legitimacy from the authorities.

The approach used in the preparation of PLBN Standard Operating Procedures (SOP) is based on several approaches, namely: a.) Formal Legal Approach, namely the preparation of Standard Operating Procedures (SOP) based on applicable regulatory provisions, both concerning the substance and format used. b.) Participatory approach, namely the preparation of Standard Operating Procedures (SOPs) as much as possible to open space for involvement of related units where Standard Operating Procedures (SOPs) will be enforced. While the principles used in the preparation of PLBN Standard Operating Procedures (SOP) are as follows: a.) Ease and Clarity. b.) Efficiency and Effectiveness. c.). Harmony. d.) Measurability. e.) Dynamic. f.) User-oriented. g.) Legal Compliance. h.) Legal Certainty.

\section{Results and Discussion}

One of the important efforts in realizing good governance is the formulation of Standard Operating Procedures (SOPs) in each government administration unit. It is hoped that the drafting of the Standard Operating Procedures (SOP) will be able to provide guarantees for the management of government administration and services to the public in a 
sure, transparent, fast and professional manner. Standard Operating Procedures are a series of standardized written instructions regarding the various processes of carrying out government administration, how and when they must be carried out, where and by whom. Standard Operating Procedures can be seen as a series of standardized written instructions regarding the process of carrying out the tasks of the Government. Preparation of Standard Operating Procedures (SOP) can provide benefits in the delivery of services to the community.

Procedurally, the process of preparing Standard Operating Procedures can be carried out through three main stages, namely: The preparation stage includes activities; Standard Operating Procedures; Operational Procedure. The Preparation Phase is the stage in which the data collection is carried out. Data needed in this activity includes: Document data, which includes: Regulations relating to the duties and authorities possessed by various units in the PLBN. Legal regulations related to standardized activities and several other documents; Primary Data which includes data from interviews with sources mentioned above and observations related to the preparation of Standard Operating Procedures. The analysis phase in the preparation of the PLBN Standard Operating Procedures includes the following analysis activities: Analysis / Assessment of Needs of SOP (Need Assessment); SOP format identification; Drafting / Writing Draft of Standard Operating Procedure (SOP).

\section{SOP Needs Analysis / Assessment}

SOP needs assessment is basically the first step in the preparation of SOPs. There are two main activities in this stage, namely: first, reviewing the existing SOPs to be evaluated, whether they are still in accordance with developments or not. If it is still relevant it can still be used, but if it is not relevant it can be adjusted. Second, compile SOPs for activities that are not standardized. The steps used in the assessment of SOP needs are as follows: Compiling a needs assessment action plan, conducting a needs assessment, making a list of SOPs to be developed, making an SOP needs assessment document. Basically a good SOP format is one that can provide a forum and can transmit the required information appropriately and facilitate the implementation of a consistent SOP. In principle, the SOP format can be done in several forms, namely: Simple Steps (Simple Steps), This simple step is used if the procedure to be compiled only contains a few activities and requires a few 
decisions. Only a few people carry out standardized procedures. Sequential Stages (Hierarchical Steps), Used for activities that are arranged quite long, more than 10 steps and require more detailed information but only requires a little decision making. Graphic (Graphic). This format is used if the compiled procedure requires a long and specific activity. Flowchart. The flow diagram format is used if a lot of decision making is needed in the SOP. The SOP writing that will be used is the format as specified in the main PLBN institutional.

PERMENPAN Number: PER / 21 / M. PAN / 11/2008, SOP Writing basically involves 3 main activities, namely: a). Information Collection. Data obtained from various methods as explained above are sources of information for writing SOP. At this stage various SOP possibilities can be developed. b.) Analysis and selection of Alternatives. Based on the principles of the preparation of SOPs, various SOP writing alternatives are chosen based on these principles. c.) Writing SOP. SOP is written based on a predetermined format. PLBN consists of several main activity processes which can then be translated into activities and sub-activities. SOP compilation includes the preparation of procedures for each activity or procedure for each sub-activity and even for sub-activities.

Figure 2. In general, examples of the scope of PLBN activities include the following:

02 Immigration

021 Cross-border document services and checks @ PROCESS

0211 SOP Passport services and checks

0212 SOP of Pas-border cross-border service and inspection

022 Handling of border crossers without documents

023 Etc ...

03 Customs

031 Baggage inspection and services $<40 \mathrm{~kg}$

0311 SOP Inspection of luggage with a Scanner

0312 SOP Manual luggage inspection

032 Cargo service and inspection $>40 \mathrm{~kg}$

033 Etc.

04 Quarantine 
041 Health Quarantine

042 Animal quarantine

05 PLBN Management Unit

051 Internal management

0511 General Administration

0512 Accounting and finance

052 External management

0521 Canteen (Food court) and Cafe

0522 Mini market

Source: processed by researchers 2018

\section{One-Stop Service As An Effort To Improve Service Quality}

As mentioned at the outset that it has become an agreement that good governance at all levels of government institutions must be based on the principles of the administration of a new government that is based on a set of laws which are essentially: (1) governance must be based on a new spirit reflecting brokrasi reform (2) the administration of government must be based on a clean and authoritative government free from Collusion, Corruption and Nepotism and (3) the administration of government must be oriented to interests and services to the people quickly, cheaply and easily.

The purpose of the implementation of governance that bases itself on the provisions as mentioned above is in addition to increasing the effectiveness and efficiency of government institutional performance, it is also intended to improve service delivery to the public. Government institutions at every level of government are required to be able to provide services in accordance with community expectations and community needs. The desired pattern of public service based on the spirit of bureaucratic reform is public service that draws closer to the party being served. The service pattern that is desired, desired, and expected by the community is a service pattern that is faster, cheaper, and better. To fulfill the desires and expectations of the people served, service providers must be closer, faster, and better. For this reason, every process of governance requires changes and improvements in terms of vision, mission, approach, and strategy in the administration of government and services to the community. This change is in response to the demands and changes in the 
development paradigm that are more community-oriented as well as an increase in services that are more efficient and professional.

UNDP (Sedarmayanti, 2003) mentions the character of governance that is oriented towards good governance has the following characteristics: Participation, Rule of Law, Transparency, Responsivness, Consensus Orientation, Effectiveness and Efficiency, Accountability and Strategic Vision. With a variety of provisions and the spirit of government administration, government institutions must be able to innovate in improving the quality of public services so that the impression of a slow, convoluted, unfriendly government bureaucracy can be eliminated. The aspiration to realize a professional and capable and accountable government bureaucracy is a concrete manifestation of the implementation of the principles of good governance. The patterns of public service in practice can basically be grouped as follows: Functional patterns; Centralized pattern; Integrated pattern; and the task force pattern.

Functional service patterns are public services provided by service providers in accordance with their duties, functions and authorities. For example, tax services will be handled by organizational units that function to collect taxes, for example KPPD (Regional Tax Service Office), electricity supply by PLN, telephone network arrangements by PT Telkom, and so on. The pattern of centralized services is that public services are provided solely by the service provider based on the delegation of authority from other relevant service providers concerned. In other words, it can be said that the pattern of public services carried out by a government agency acting as coordinator of the services of other agencies related to the field of public services concerned. For example, the management of passport services by the Immigration Office, birth certificate by the Civil Registry office, etc.

The integrated service pattern consists of two forms, namely: a) Integrated One Roof. The one-stop integrated service pattern is held in one place which includes various types of services that do not have a process interrelation and are served through several doors. There is no need for one type of service to be close to the community. b.) Integrated One Door. The one-stop integrated service pattern is held in one place which covers various types of services that have process interrelations and are served through one door. Aside from providing one-stop service, there are other things that deserve attention in order to improve service performance. According to Moenir (1998), so services can satisfy the person or group 
of people served, there are four basic requirements that must be done by the company, namely (1) polite behavior, (2) how to convey something related to what should be received by the person concerned, (3) the exact time of delivery, and (4) hospitality. Supporting factors that are not less important than satisfaction include the awareness factors of officials or officers working in public services, regulatory factors that form the basis of service work, organizational factors which are tools and systems that enable the operation of service activities, revenue factors that can meet the needs minimum life, staff skill factor, and facility factor in implementing service tasks.

Meanwhile, according to Parasuraman (in Prianto, 2006) it is stated that there are five dimensions that must be considered in measuring service quality, namely: (1) tangible dimensions, (2) reliability dimensions, (3) responsiveness dimensions, (4) assurance dimensions and (5) empathy dimensions. Tangible dimensions involve something that can be observed physically related to services, such as: physical office buildings, equipment, procedures, requirements and the like. The reliability dimension is related to the degree of reliability of the public service apparatus in providing services. This dimension relates to the speed and accuracy of public service institutions and their apparatuses in carrying out their service activities. Meanwhile the responsiveness dimension is related to responsiveness to complaints, hopes and changes in the community. This dimension is related to a proactive attitude and is always alert for public service officers towards what happens in the community. The assurance dimension is related to the issue to what extent the ability of the institution and its officials to instill trust and confidence in the customers or communities served. The ability, skills and friendliness of service officers will encourage public trust in public service institutions. Whereas the empathy dimension is related to the existence of caring and caring attitudes towards every community that receives services.

In addition to efforts to simplify service paths through the concept of integrated services, improvements in service delivery can be done through changes in the governance system, while not forgetting improvements to human resources or institutions. . Governance must be able to provide guarantees to implementing officers in carrying out their respective duties and functions in the context of the realization of the principle of professionalism. 


\section{Conclusion}

PLBN consists of several main activity processes which can then be translated into activities and sub-activities. Standardization of Integrated PLBN Development includes technical standardization of PLBN buildings and standardization of Integrated PLBN management. In this activity will be carried out the preparation of the Integrated PLBN management standardization namely standardization of the work mechanism of the more popular PLBN with the term Standard Operating Procedure (SOP) or Permanent Procedure (SOP). SOP preparation includes the preparation of procedures for each activity or procedure in each sub-activity and even in sub-activities. The SOPs that need to be made in the 4 main activities of the National PLBN, which are detailed according to the activities and sub-activities of the main activity process, are 4 large groups of SOPs that will be made in separate reports as follows: Immigration SOPs; Customs SOP; Quarantine SOP; SOP UP PLBN. In addition PLBN needs to be addressed and implemented a one-stop integrated service pattern (integrated) which is held in one place which includes various types of services that have process links and are served through one door.

\section{References}

Abdul Wahab, Solikin, Analisis Kebijakan, Bumi Aksara, Jakarta, 2001

Bennis, Warren G, Changing Organization, Mac. Graw Hill, New York, 1969

Barata, Atep Adya , Dasar Dasar Pelayanan Prima, PT Elek Media Komputindo, Jakarta, 2004

Gibson, at al, Organisasi dan Manajemen, Erlangga, Jakarta, 1984

Herbert G Hicks dan G Ray G, Organisasi Teori dan Tingkat Laku, Bumi Aksara, Jakarta, 1996

Lembaga Administrasi Negara, Organisasi dan Metode, Jakarta 1979.

Miftah, Thoha, “Pembinaan Organisasi” PT Radja Grasindo, Jakarta,2002

Moenir, Menakar Kualitas Pelayanan Publik, In TRANS, Malang, 1998

Pramusinto. Agus \& Erwan AP (ed), Reformasi Birokrasi, Kepemimpinan dan Pelayanan Publik, Penerbit Gava Media, Yogyakarta, 2009 
Prianto, Edisi Ke-empat. Prinsip-prinsip Total Quality Service (TQS). Yogyakarta: ANDI, 2006

Sedarmayanti, Organizational Behaviour, Prentice Hall International Edition, New Jersy, 2003

Wibisono, “Efektif”,Aguswibisono.com, 14 Maret 2010

PERMENPAN Nomor : PER/21/M. PAN/11/2008 tentang Pedoman Penyusunan Standar Operating Prosedur (SOP) Administrasi Pemerintahan

Peraturan Menteri Dalam Negeri Nomor 24 Tahun 2006 tentang Pedoman Penyelengaraan Pelayanan Terpadu Satu Pintu 